\title{
Capitalist Crisis, Communication, \& Culture - Introduction to the Special Issue of tripleC
}

\section{Christian Fuchs ${ }^{1}$, Matthias Schafranek ${ }^{2}$, David Hakken ${ }^{3}$ and Marcus Breen $^{4}$}

${ }^{1}$ Department of Informatics and Media, Uppsala University, Sweden, christian.fuchs@im.uu.se

2 Unified Theory of Information Research Group, Austria, matthias.schafranek@sbg.ac.at

${ }^{3}$ School of Informatics, Indiana University, Bloomington, USA, dhakken@indiana.edu

${ }^{4}$ Department of Communication Studies, Northeastern University, Boston, USA, m.breen@neu.edu

\begin{abstract}
The worldwide economic downturn is indicative for a new large crisis of capitalism. The future of capitalism is in this situation not determined, but depends on collective human agency. This introduction to the special issue of tripleC on "Capitalist Crisis, Communication \& Culture" presents general arguments about the crisis, a general model of the political economy of capitalist communication, and a systematic typology of literature about capitalist crisis \& communication. The introduced model of the political economy of capitalist communication is comprised of seven interconnected moments: 1) the media content industry, 2) the media infrastructure industry, 3) the interaction of the media economy and the non-media economy, 4) the interaction of the finance sector and the media economy, 5) alternative media, 6) media reception, 7) media prosumption. The model is used for classifying actual and potential research about the communicative dimension of the new capitalist crisis.
\end{abstract}

Keywords: crisis, capitalism, finance, financial crisis, communication, media, culture, information technology, information society

\section{The Capitalist Crisis}

The global economic slump is an indicator of a new world economic crisis. Foster and Magdoff (2009) speak in this context of "the great financial crisis", Paul Krugman (2009) of "the return of depression economics". The growth rate of world GDP dropped from a rate of $3.8 \%$ in 2007 to $1.7 \%$ in 2008 (figure 1). The crisis shows that the 1990s talk about the new economy constituting a new world economic growth wonder has finally proved false and that neoliberalism as policy for smooth development of society and the economy has failed and is based on false assumptions. Figure 1 shows the development of the worldwide GDP since 1961. The high growth rates characteristic for Fordist capitalism came to an end in 1974/1975, when the second world economic crisis hit capitalism. Ever since economic development has been very instable and in constant flux. Phases of crises were clearly perceivable in 1982, the early 1990s, at the turn of the millennium. The current situation is therefore indicative of the crisis-proneness and instability of the world system. The crisis took effect in the US housing market in 2007 and spread subsequently all over the world. This shows the networked and global character of financial markets and the capitalist economy. 


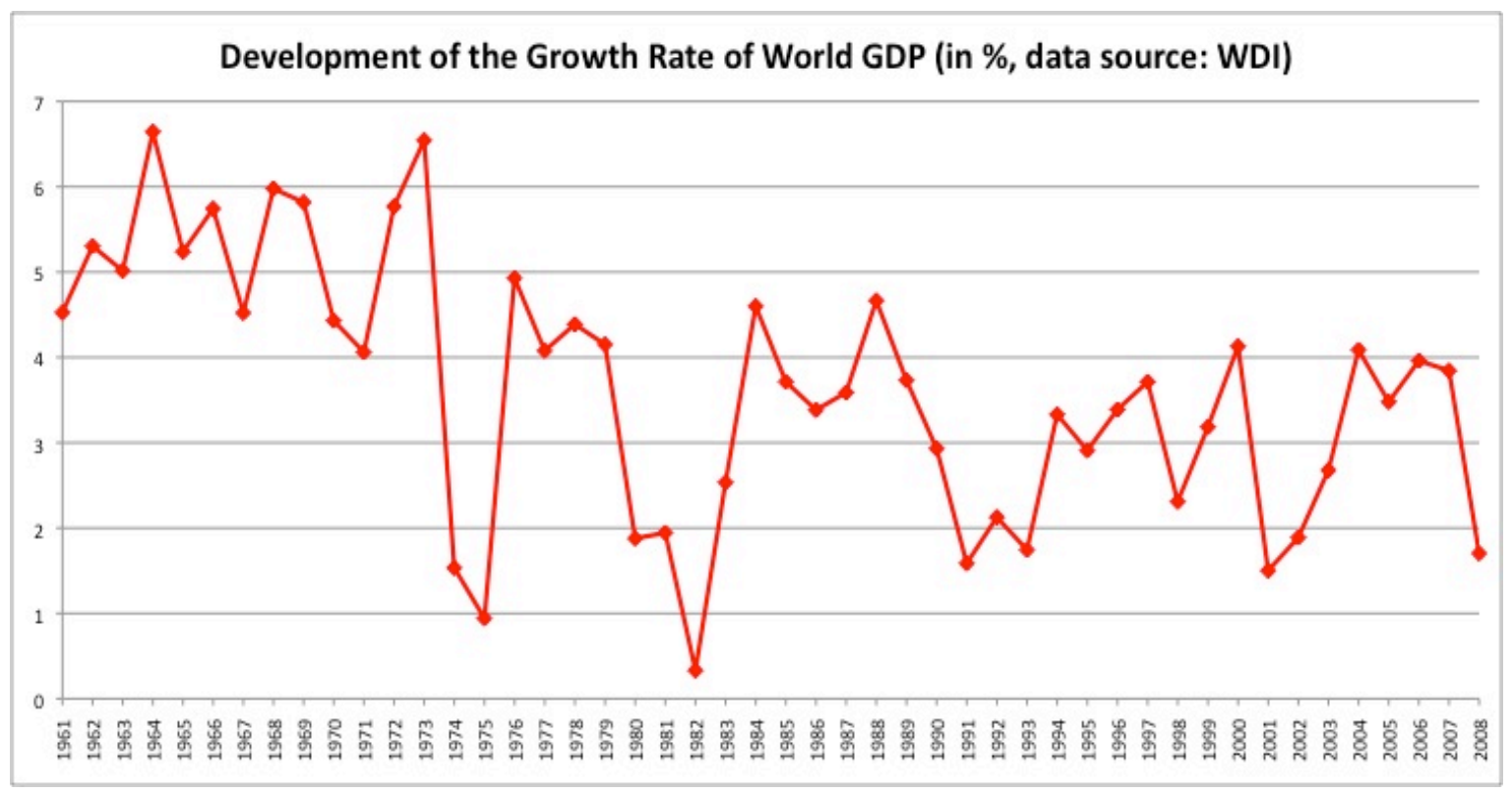

Figure 1: The development of world economic growth in the years 1961-2008

Some key events of the crisis:

- In July 2007, two hedge funds of Bear Stearns collapsed.

- On August $9^{\text {th }}, 2007$, the French bank BNP Paribas told its investors that two of its hedge funds were illiquid.

- In January 2008 , the oil price reached the critical mark of US\$100. It continued to rise to almost US\$ 150 in the middle of the same year.

- In February 2008, the UK government nationalized Northern Rock because of liquidity problems of the bank.

- In July 2008, the US mortgage bank IndyMac (Independent National Mortgage Corporation) collapsed and was taken into conservatorship by the Federal Deposit Insurance Corporation (FDIC).

- On September $7^{\text {th }}, 2008$, Freddie Mac (Federal Home Loan Mortgage Corporation) and Fannie Mae (Federal National Mortgage Association), two government-sponsored enterprises that suffered huge losses from the trade with mortgage-backed securities, were taken into conservatorship by the Federal Housing Finance Agency.

- On September $15^{\text {th }}, 2008$, the financial services firm Lehman Brothers declared bankruptcy. On the same day the financial services firm Merrill Lynch was sold to the Bank of America after it had suffered tremendous losses.

- On September $16^{\text {th }}$, the US Federal Reserve rescued the country's largest insurance company AIG from bankruptcy.

- On September $29^{\text {th }}$, the US House of Representatives passed the Emergency Economic Stabilization Act.

- On October $3^{\text {rd }}$, the US Senate voted on the bill, which was then enacted into law. The act enabled the US government to inject 700 billion US $\$$ into the financial markets by bailing out crisisridden banks, offering financial support to financial institutions, and buying troubled assets, credits, and equity.

- At the beginning of October 2008, the major banks (Glitnir, Landesbanki, Kaupthing) in Ireland were nationalized by the government. In the same month, the German government bailed out Hypo Real Estate, a German mortgage lender.

- On October $8^{\text {th }}$, the UK government announced a bail out plan of 50 billion $£$.

- On October $17^{\text {th }}$, the German Bundestag authorized a 500 billion $€$ bank bail out. 
- On November $20^{\text {th }}$, the Dow Jones Industrial Average closed at 7,552.29 points, which was the lowest value in six years.

- On December $19^{\text {th }}$, the US government approved a bailout of 13 billion US $\$$ for Chrysler and General Motors.

- On January $19^{\text {th }}, 2009$, the Royal Bank of Scotland made public that it made the largest losses in UK history in 2008. The results were huge share losses of UK banks.

- On March $9^{\text {th }}, 2009$, the Dow Jones closed at 6,469.95 points, the lowest value since April 1997.

There is a group of authors that argues that the crisis is a result of regulation failures and deregulated finance markets (Gowan, 2009; Stiglitz, 2008, 2009, 2010; Krugman, 2009) and another group of authors that argues that the crisis is a systemic and structural crisis of capitalism caused by structural crisis tendencies inherent in the capitalist system and the stagnation of wages resulting from the class struggle fought by economic and financial elites against the working class (Bischoff, 2008; Brenner, 2009; Callinicos, 2010; Foster and Magdoff, 2009; Hardt \& Negri, 2009; Harman, 2010; Harvey, 2009, 2010; Lapavitsas, 2009; Moseley, 2009; Wolff, 2008). Depending on which of these two analyses one shares, there will be different policy conclusions. The first group of authors argues that a more regulated, neo-Keynesian economy is needed, in which especially financial speculation is controlled, the second group of authors says that the crisis shows that capitalism is inherently creating misery through crisis and therefore needs to be replaced by a system of participatory grassroots socialism. Notwithstanding which position one takes, it is interesting to observe how most hardcore neoliberal politicians, journalists, managers, bankers, and financial consultants turned there back on Friedrich August von Hayek and Milton Friedman over night and suddenly emerged as neo-Keynesians (many of them even claimed that they had always been Keynesians).

It is not an unrealistic possibility, but - given for example the latest election results in Europe, which do not signify a shift towards the political left, but towards the political right - rather a quite likely political development, that the capitalist crisis will work, as Naomi Klein (2007) says, as a shock doctrine that ideologically legitimates the establishment of even more brutal forms of capitalism. "That is how the shock doctrine works: the original disaster - the coup, the terrorist attack, the market meltdown, the war, the tsunami, the hurricane - puts the entire population into a state of collective shock. The falling bombs, the bursts of terror, the pounding winds sere to soften up the whole societies much as the blaring music and blows in the torture cells soften up prisoners. Like the terrorized prisoner who gives up the names of comrades and renounces his faith, shocked societies often give up things they would otherwise fiercely protect" (Klein, 2007, p. 17). But the resurgence of neoliberalism and capitalism is only one possible outcome of the crisis. Authors like Slavoj Žižek (2009a, 2010) remind us that ideology plays a role in the reactions to crises, but that there are at the same time potential alternatives.

The current crisis is not simply a crisis of finance or a housing crisis, but a crisis of capitalism. Žižek (2010) suggests in this context in his book Living in the end times that capitalism is in crisis and "is approaching an apocalyptic zero-point. Its 'four riders of the apocalypse' are comprised by the ecological crisis, the consequences of the biogenetic revolution, imbalances within the system itself (problems with intellectual property: forthcoming struggles over raw materials, food and water), and the explosive growth of social divisions and exclusions" (Žižek, 2010, p. x). Whereas in Living in the end times, Žižek does not engage in a deeper analysis of this crisis and the common features of the four dimensions, he has pointed out in other publications that the crisis has to do with the exploitation of the commons: Zižek (2009a, b) says that the privatization and exploitation of the commons of culture, external nature, and internal nature, and the exclusions of humans from wealth dispossesses them of the foundations of life, it "renders us all proletarians", who are "in danger of losing everything" (Zižek, 2009a, p. 92). Žižek (2010) applies Elisabeth Kübler-Ross's five stages of grief (denial, anger, bargaining, depression, acceptance) to capitalist crisis-reactions. Although it is problematic to suggest, as Žižek does, that reactions to the crisis run subsequently through stages and thereby go from ideological denial via anger, attempted reforms, and depression after failed reforms, towards a new beginning, he makes an important point when suggesting 
that the proper reaction to the crisis is "that the subject no longer perceives the situation as a threat, but as the chance of a new beginning" and when saying that one should view the crisis by saying "There is a great disorder under heaven, the situation is excellent" (Žižek, 2010, p. xii).

Žižek does not outline what it exactly means that capitalism has reached a zero-point. At the zero-point, water reaches a critical point in its structural development, a threshold of one of its parameters is reached so that quantity turns into the emergence of a new quality: reaching a quantitative value of zero degree temperature, the aggregate condition of water turns from the quality of water into the quality of ice. Or as Hegel put it: "Thus the temperature of water is, in the first place, a point of no consequence in respect of its liquidity: still with the increase of diminution of the temperature of the liquid water, there comes a point where this state of cohesion suffers a qualitative change, and the water is converted into steam or ice" (Hegel, 1874, §108).

Dialectical development is development by contradictions, in the realm of society a dialectic is never automatically exploded into participatory humanity through structural antagonisms, but requires active political struggles to do so (Fuchs, 2010b, chapter 2). We should therefore interpret the zero-point of capitalism not as meaning the automatic breakdown of capitalism, but one should add to Žižek's analysis that the capitalist zero-point reached in the crisis signifies in a more modest dialectical sense that the system will change its quality at a certain organizational level: 1 ) it could be the emergence of a qualitatively new form of neoliberal capitalism, 2) the emergence of a more regulated, neo-Keynesian form of capitalism, 3) the rise of fascist forms of capitalism, 4) a long time of conflict and global wars, or 5) the emergence of a participatory society and economy. The results are not predetermined, but depend on conditions, i.e. if social struggles are organized and if so, what their results are. "We may think of this period of systemic crisis as an arena of struggle fort he succesor system" (Wallerstein, 2010, p. 140). Whereas the resurgence of neoliberal capitalism or Keynesianism does not bring about change at a systemic level, but mainly at the policy level, and the fascist and the global war alternatives mainly mean change as the rise of new forms of brutal direct violence, the fifth option means a deeper emancipatory change that establishes nondominative structures. The meaning of the zero-point of capitalism is that there are different development options in the crisis that are not pre-determined, but decided by class struggles. This meaning is not pointed out by Žižek (2010) in Living in the end times, but was hinted at in a BBC interview, where he said that the zero-point means that we are "approaching some terminal point, [...] where something will have to change" (interview with Slavoj Žižek on BBC Newsnight, http://www.youtube.com/watch?v=Pb50-117dQQ\&feature=related, accessed on August 1, 2010). Žižek $(2009 a, 2010)$ reminds us that the crisis means that capitalism ever and ever again produced, produces, and will produce misery (for workers losing their jobs, capitalists losing their firms, people dying or living deprived of a humane existence, etc), and that therefore it is right now the right time for thinking about alternatives to capitalism and for acting according to this insight.

The need for discussing alternatives has been most explicitly formulated by the French philosopher Alain Badiou (2010). He compares contemporary crisis capitalism to capitalism in the 1840s: "Just as in around 1840, today we are faced with an utterly cynical capitalism, which is certain that it is the only possible option for a rational organization of society. [...] Today, just as back then, very extensive areas of extreme poverty can be found even in the rich countries. There are outrageous, widening inequalities between countries, as well as between social classes" (Badiou, 2010, pp. 258f). "More than ever, political power, as the current economic crisis with its one single slogan of 'rescue the banks' clearly proves, is merely an agent of capitalism" (Badiou, 2010, p. 259). Badiou says that the call "save the banks" shows that there is not an "end of ideologies" (Badiou, 2010, p. 99) and that therefore today nothing "could be more important than rediscovering the passion for ideas" (Badiou, 2010, p. 100). Therefore a general hypothesis that "we can create a very different order of things" (Badiou 2010, 100) would be needed. Therefore a counter-idea would be needed. Badiou says that "we have to be bold enough to have an idea" (Badiou, 2010, p. 66). This counterhypothesis would mean "to cling to the historical hypothesis of a world that has been freed from the law of profit and private interest" (Badiou, 2010, p. 63), a world that is an association, "in which the free development of each is the condition for the free development of all" (Badiou, 2010, p. 100). 
This counter movement, Badiou argues, should also rejoice in "fidelity to May '68" (Badiou, 2010, p. 66).

The third chapter of Žižek's Living in the end times holds the title "The return of the critique of the political economy" (Žižek, 2010, pp. 181-243). Žižek here points towards important necessary changes of academia: whereas since the 1990s up until today, approaches of critical political economy that are grounded in the works of Karl Marx were broadly dismissed as outdated and problematic, the new capitalist crisis necessitates an intellectual engagement with notions such as capital, capitalism, capitalist crisis, dialectics, surplus value, accumulation, and class. Whereas the postmodern turn has resulted in a neglect of economic issues in the social sciences in general and in the analysis of media, culture, information, and communication in particular, a renewal of the interest in the just mentioned economic topics and in critical study approaches (Fuchs, 2010b) is needed today. Our special section of tripleC on Capitalist Crisis, Communication \& Culture is an application of Žižek's reminder of the necessity of critical political economy-analyses to the realm of media/cultural studies and information science (see also Fuchs, 2010b; Breen, 2010).

\section{A Systematic Typology of the Political Economy of Capitalist Communication}

Other then in the new economy crisis in the year 2000 that was triggered by a financial bubble in the ICT market, the focus of press coverage and public discussion in the new crisis has primarily been on banks and the housing market. There has not been much news on how the information economy has been affected by the new crisis. There were a few exceptions, such as the coverage on the 16 billion US $\$$ loss of Time Warner in 2008 (NY Times, February 4, 2009), the write-down of 5.1 billion US $\$$ by Alcatel-Lucent (NY Times, February 4, 2009), the 8 billion US\$ write down by News Corporation (NY Times, February 5, 2009), or a planned cut of 5,000 jobs by Intel (NY Times, January 21, 2009); additionally, the accelerated decline of the US newspaper industry in the last three years due to crisis-related cutbacks of the industry's lifeblood, ad revenue, as well as the latter's successive migration to the web 2.0 business field has drawn broader attention to the information economy in the crisis too, at least in the United States (NY Times, March 11, 2009). But overall not much is known about the relation of the current crisis to the information economy.

The main focus of most public debates as well as of economic and policy analyses is the role of finance capital and the housing market in creating the crisis, less attention is given to the role of communication technologies, the media, and culture in the world economic crisis. The task of this special section of tripleC is to present analyses of the role of ICTs, the media, and culture. The presented papers focus on the causes, development, and effects of the crisis. Each paper relates one or more of these dimensions to ICTs, the media, or culture.

That there is a need for such analyses is indicated by the two other special issues on comparable topics that were recently published. The International Journal of Communication (Vol. 4, 2010) featured four papers in a special section on "Global Financial Crisis" (edited by Paula Chakravartty and John H. Downing), Cultural Studies (Vol. 24, No. 3) published a special issue on "The Economic Crisis and After". The seven papers presented in tripleC's special issue on "Capitalist Crisis, Communication \& Culture" share with the papers published in these two special issues the focus on media and culture. Besides a focus on media and culture and the crisis, they also give special attention to computing and ICTs in the crisis.

The task of this introduction is to systematically classify actual and potential research about capitalist crises, communication, media, culture, and ICTs. For doing so, a model of how the capitalist media economy works is needed (see Fuchs, 2010b, chapter 4; Fuchs, 2010c).

The model in figure 2 summarizes the connection of four aspects of the media (see Fuchs, $2010 \mathrm{~b}$, chapter 3), i.e. four roles of the media in the capitalist economy:

1. the commodity form of the media,

2. the ideological form of the media,

3. media reception,

4. alternative media. 
It focuses on the role of the media in the production, circulation, and consumption processes of the economy, not on the relations to the political system (state, civil society, laws, etc) and cultural institutions (education, family, religion, etc). Capital accumulation within the media sphere takes place in both the media content sphere and the media infrastructure sphere. These two realms together form the sphere of media capital. The circuit of capital M-C..P-C'-M' (money - commodities ... production - new commodity - more money; see Fuchs, 2010b, for details) is shown for each of the two realms, which indicates that they are oriented on capital accumulation.

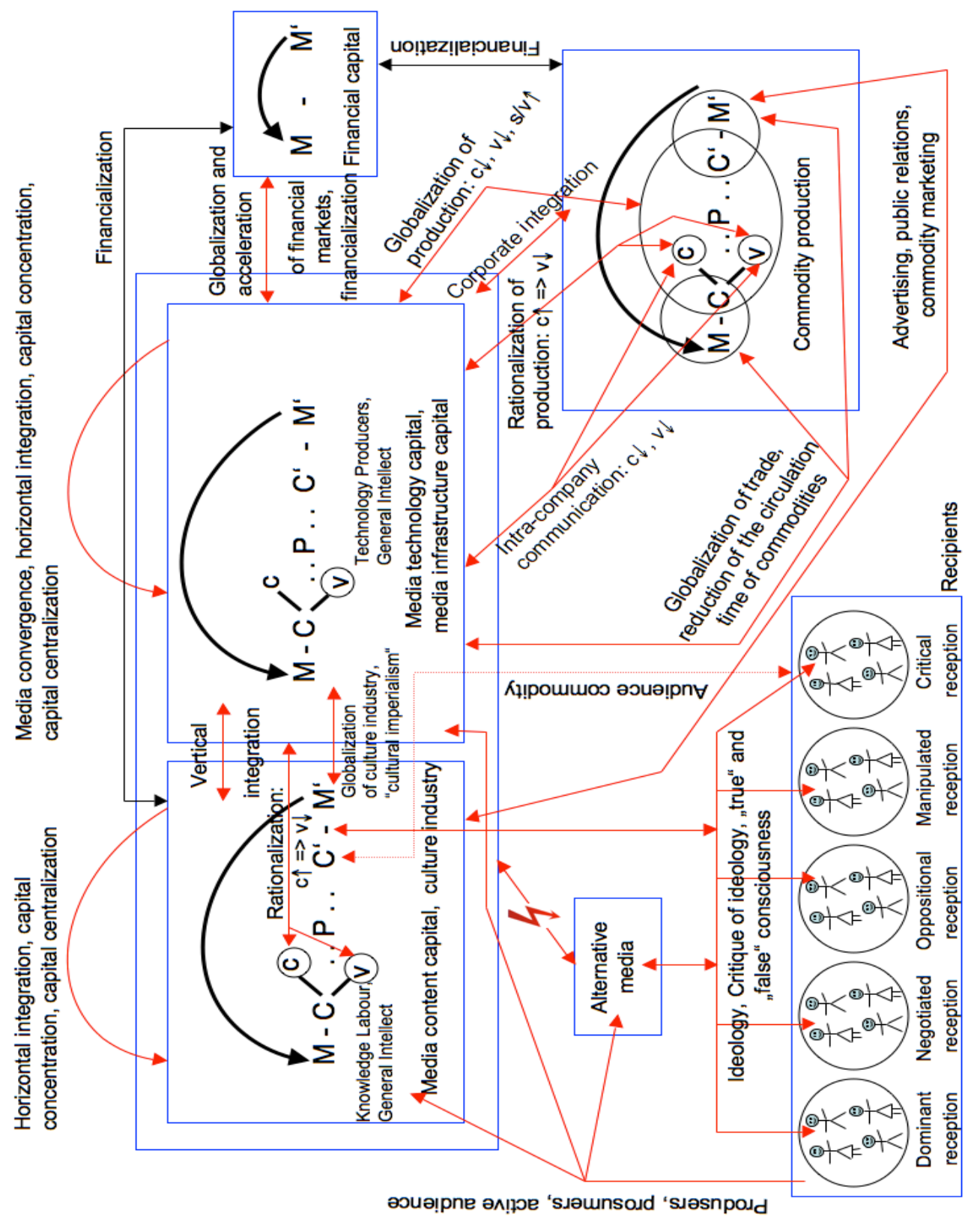

Figure 2: The capitalist media economy = the processes of media production, circulation, and consumption in the capitalist economy

The commodity aspect of the media can be visualized as the following processes that are shown in figure 2: vertical and horizontal integration, media concentration, media convergence, media globalization, the integration of media capital and other types of capital, the rationalization of production, the globalization of production, circulation, and trade; intra-company communication, ad- 
vertising and marketing. Processes of vertical integration make the boundaries between the two systems fuzzy. Concentration processes and horizontal integration, which are inherent features of capital accumulation, shape each of the two spheres. Media convergence is a specific feature of media infrastructure capital. The two realms together are factors that influence the globalization of the culture industry. The realm of the economy that is shown at the bottom right of figure 2 is the one of capital accumulation in non-media industries and services. It is partly integrated with the media sector due to corporate integration processes. Media technologies advance the rationalization of production in this realm as well as in the media content industry. Furthermore they advance the globalization of production, circulation, and trade. These globalization processes are also factors that in return advance the development of new media technologies. Media technologies are also used for intra-company communication. Rationalization, globalization, and intra-company communication are processes that aim at maximizing profits by decreasing the investment cost of capital (constant and variable capital) and by advancing relative surplus value production (more production in less time). The media content industry is important for advertising and marketing commodities in the circulation process of commodities, which is at the same time the realization process of capital, in which surplus value is transformed into money profit.

The ideology aspect of the media is visualized in figure 2 by media content capital and its relation to recipients. Media content that creates false consciousness is considered as ideological content. Media content depends on reception. The reception hypothesis is visualized in the lower left part of figure 2. Reception is the realm where ideologies are reproduced and potentially challenged.

Alternative media is a sphere that challenges the capitalist media industry. Alternative media are way of organizing and producing media that aim at creating critical content that challenges domination. Alternative media are visualized in figure 2 by a separate domain that stands for alternative ways of organizing and producing media that aim at creating critical content that challenges the capitalist media industry. Media content depends on reception. Five forms of reception are distinguished in the left lower left part of figure 2.

Reception is the realm where ideologies are reproduced and potentially challenged. In some types and parts of media content, capital is accumulated by selling the audience as commodity to advertising clients. Dallas Smythe (1981/2006) spoke in this context of the audience commodity. As advertising profits are not a general feature of all media capital, there is a dotted line in figure 2 that signifies the audience commodity. In recent times, recipients have increasingly become an active audience that produces content and technologies. In this context, the notion of produsers (producer + user) and prosumers (producer + consumer) can be employed. Produsage and prosumage can both advance media capital accumulation (Fuchs, 2010d) and alternative media production.

The use value of media and media technologies is that they allow humans to inform themselves and to communicate. In capitalist society, use value is dominated by the exchange value of products, which become commodities. The media take on commodity form, their use value only becomes available for consumers through exchanges that accumulate money capital in the hands of capitalists. Media and technologies as concrete products represent the use value side of information and communication, whereas the monetary price of the media represents the exchange value side of information and communication. The commodity hypothesis discusses the exchange value aspect of the media. The ideology hypothesis shows how the dominance of the use value of the media by exchange value creates a role of the media in the legitimatization and reproduction of domination. The two hypotheses are connected through the contradictory double character of media as use values and exchange values. The media as commodities are in relation to money use values that can realize their exchange value, i.e. their price, in money form. Money is an exchange value in relation to the media. It realizes its use value in the media commodities. Consumers are interested in the use value aspect of media and technology, whereas capitalists are interested in the exchange value aspect that helps them to accumulate money capital. The use value of media and technology only becomes available to consumers through complex processes, in which capitalists exchange the commodities they control with money. This means that the use value of media and technology is only possible through the exchange value that they have in relation to money. 
Commodification is a basic process that underlies media and technology in capitalism. Use value and exchange value are "bilateral polar opposites" (MEW, Vol. 13, p. 72) of media and technology in capitalist society. Once media and technology reach consumers, they have taken on commodity form and are therefore likely to have ideological characteristics. The sphere of alternative media challenges the commodity character of the media. It aims at a reversal so that use value becomes the dominant feature of media and technology by the sublation of their exchange value. Processes of alternative reception transcend the ideological character of the media - the recipients are empowered in questioning the commodified character of the world they live in.

Based on this model of the media economy, we can identify the following interlinked analytical aspects:

1. The media content industry

2. The media infrastructure industry

3. The interaction of the media economy and the non-media economy

4. The interaction of the finance sector and the media economy

5. Alternative media

6. Media reception

7. Media prosumption

\section{A Typology of Research on Capitalist Crisis, Communication \& Culture}

These distinctions among the seven aspects of the media economy allows us to identify topics for the analysis of capitalist crisis and media/communication/ICTs/culture.

\section{The media content industry}

Topics include the effects of the crisis on the media content industry, the coverage of the crisis in the media, the role of advertising and the media in creating a climate that favours private consumer debt.

Fuchs (2010b) has analyzed how the media content industry has been affected by the crisis with the help of statistics of the profits, market values, assets, etc of world's largest companies.

Chakravartty and Schiller (2010) have stressed that business journalism as a result of the crisis now tends to promote neo-Keynesianism. They argue that business journalism has been dominated by a neoliberal newspeak that celebrates neoliberalism and can be considered as being a form of cultural imperialism.

McChesney, Foster, Stole and Holleman (2009) have analyzed the role of advertising in reinforcing the "buy now, pay later" ethos that the financial sector needed for its expansion. The same analysis is advanced by Chakravartty and Schiller (2010).

Hope (2010) argues that real estate advertising encouraged homeowners to remortgage their homes. McChesney and Nichols (2010a, 2010b) argue that the economic crisis has made apparent a crisis of news journalism.

Furthermore, circulation of unregulated media content on the Internet was a core component of the shift from the regulated analog media of pre-digital era and part of the new ideological terrain that encouraged financial hyperactivity. The forces that argued for the networking of all digital content have been able to offer powerful tools to leverage their own interests within the neo-liberal imagination by taking advantage of the unregulated space. It is a game of smoke and mirrors where considerable research is still required to make sense of how the pieces of media and communication industries fit together (Rossiter, 2006). Indeed, critical work on convergence is needed to explore the contradictory yet co-joined fields of entertainment, information and epistemology while advancing new definitions of "the public interest" and "civil society" in response to the challenges facing humankind.

\section{The media infrastructure industry}


The main topic of this dimension is the analysis of the effects of the crisis on the media infrastructure industry (telecommunications, computer industry, etc).

Fuchs (2010b, chapter 6 ) shows how the media infrastructure industry's profits, market values, assets, etc have developed in the new capitalist crisis.

In the tripleC-special issue on "Capitalist Crisis, Communication, \& Culture", Rosario de Mateo, Laura Bergés, and Anna Garnatxe in their contribution Crisis, what crisis? The media: business and journalism in times of crisis analyze how the crisis has affected the Spanish media content industry. They given special attention to advertising spending and make use of a large amount of empirical data. The contribution reminds us that given the dominance of theoretical models in the analysis of the connection of finance crisis and media, culture, and information technology, it is very important to conduct empirical studies of the role of media, culture, and information technology in the crisis (see also Fuchs 2010b, chapter 6, for a combination of theoretical models and empirical analysis for global corporations).

\section{The interaction of the media economy and the non-media economy}

Topics of this research dimension are for example the analysis of the development of advertising investments in various non-media companies and industries, the ideological discourses used by companies, CEOs, and managers for justifying their role in the crisis, lay-offs, high bonuses, the analysis of the political worldviews and policy recommendations of CEOs, managers, and shareholders in relation to the crisis, or the analysis of company's reactions to the crisis and discourses related to the crisis in strategic company documents (as for example corporate social responsibility reports).

\section{The interaction of the finance sector and the media economy}

Topics for analysis include for example the role of ICTs in the globalization and acceleration of financial markets, the role of ICTs in creating new high-risk financial instruments, the role of finance capital in the media industries, or the connection of the new economy crisis 2000 and the housing and financial crisis 2008.

Chakravarrty and Schiller argue that in the past decades, "communications industry capital channeled investments into market and financial news on a transnational scale" (Chakravarty \& Schiller, 2010, p. 686). They argue that neoliberal digital capitalism is the context of the crisis and that information has been an important spatio-temporal fix for capital in order to overcome the crisis of the 1970s and that this form of capitalism has advanced economic and financial globalization. A good example for the interconnection of ICTs and the finance sector is the rise of algorithmic trading. In algorithmic trading, computer programmes control the buying and selling of stocks and derivates. They observe finance market development and calculate which amount of stocks and derivates should be sold or bought at which point of time. Small stock value fluctuations can result in real-time buying or selling.

"The spread of algorithmic trading, for example, increasingly allowed computers to place orders without human intervention" (Hope, 2010, p. 660). As algorithmic trading is beyond human control, financial decisions are the locus of the technological rationality of machines, which can advance high-risk financial behaviour and as a result the volatility of financial markets. Hope (2010) argues that ICTs have advanced the acceleration and globalization of finance and the economy in general.

David Hakken argues in his contribution Computing and the crisis: the significant role of new information technologies in the current socio-economic meltdown, which is the opening paper of our special issue, that computerized financialization of asset ownership and the role of computing in the establishment of new high-risk financial instruments played an important role in the creation of the crisis. Hakken also argues that computing contributed to the emergence of unbounded global finance markets and tools that assess the risks of financial instruments and markets. 
Vincent Manzerolle in his contribution (in the special issue) The virtual debt factory: towards and analysis of debt and abstraction in the American credit crisis argues that the crisis is related to the disappearing body and the subsitution of flesh and blood by data. He stresses that computing is used for calculating the credit score of an individual, a score that assesses the credit-worthiness of a person. Credit scoring would be based on the surveillance of personal data and geodemographic data and would be one of the foundations of predatory lending and the commodification of debt.

Matthias Werner and Hajo Greif in their tripleC special issue paper Calculating the unknown. Rationalities of operational risk in financial institutions argue that the use of ICTs in finance is based on calculative rationality that all risks can be computed and thereby avoided. The problem according to the authors is that knowledge is complex and always involves many uncertainties.

Thomas Ruddy in his contribution to the special section of tripleC, Anglo-American credit scoring and consumer debt in the subprime mortgage crisis of 2007 as models for other countries?, analyzes the role of credit scoring techniques in creating the crisis. He relates this analysis to contemporary discourses about surveillance and social sorting. The paper connects discussions about the crisis to a specific form of information society analysis - surveillance studies.

Joelle Palmieri argues in her tripleC special issue paper Crise, genre et TIC: recette pour une schizophrénie prononcée. L'exemple de l'Afrique du Sud [Crisis, gender and ICT: recipe for a pronounced schizophrenia. The example of South Africa] that ICTs have accelerated the economy and thereby contributed to the creation of the crisis. Women would be particularly affected by the crisis, especially in African countries like South Africa. The alternative for her is a direct democracy that is connected to a knowledge economy that especially reflects the experiences of women.

\section{Alternative media}

The main topic is the analysis of the coverage of the crisis in alternative media (alternative press, public access television, alternative radio stations, alternative Internet, see Fuchs, 2010a; Sandoval \& Fuchs, 2010) and the analysis of the role of alternative media in crisis-related social movement protests.

\section{Media reception}

Research in this domain is focused on the hegemonic, alternative, or contradictory interpretations and reception practices of media audiences in relation to finance-crisis oriented media and cultural content. This domain of analysis includes also research on the ideologies and myths underlying the finance crisis.

Grossberg (2010) argues that the financial derivative is a process of capital commensuration and that culture is the broader context of the crisis. He refers to Moishe Postone for arguing that there is a crisis of measuring value. The locates the new economic crisis in two broader crisis: 1) the crisis of or struggle over temporality (that expresses itself for example in generational conflicts between the baby boomers and their kids because the first cannot accept that they have become old and project their own fears into fears about what could happen to their children), 2) the crisis of all forms of economic, political, and cultural measurement and commensuration (impossibility to find any common ground or logic). Hayward (2010) argues that the crisis has resulted in various forms of nostalgia and that moments of crisis are moments where it is possible to trouble systems of inequality and oppression. He reminds cultural studies scholars that the economy is a site of constant engagement and experimentation.

\section{Media prosumption}

This domain is specifically oriented on the analysis of the role of "web 2.0"- and "social media"platforms (Twitter, YouTube, Facebook, Wikipedia, blogs, etc) in documenting, analyzing and interpreting the crisis and finance in general. 
Hope (2010) argues that web 2.0 contains a financial blogosphere that has analyzed the financial market in order to spur investments.

\section{Conclusion}

This rough overview of studies of the connection of the new capitalist crisis to communication, culture, and information technology does not claim to be complete, yet it shows that it is possible to provide a systematic view of this discourse. Indeed, the overview suggests that some topics, especially the connection of ICTs and financialization, are popular foci of studies, whereas others have thus far received less attention.

The current capitalist crisis is a challenge for both politics and academia. It remains to be seen if critical analyses of finance, communication, \& culture will contribute to the creation and communication of alternatives to the crisis economy.

\section{References}

Badiou, A. (2010). The Communist Hypothesis. London: Verso.

Bischoff, J. (2008). Globale Finanzkrise. Hamburg: VSA.

Breen, M. (2010). Digital Determinism: Culture Industries in the US-Australia Free Trade Agreement. New Media \& Society, $12(4), 657-676$.

Brenner, R. (2009). The Economy in a World of Trouble. Against the Current, 139 (March-April 2009).

Callinicos, A. (2010). Bonfire of Illusions. Cambridge, UK: Polity.

Chakravartty, P. \& Schiller, D. (2010). Neoliberal Newspeak and Digital Capitalism in Crisis. International Journal of Communication, 4, 670-692.

Foster, J.B. \& Magdoff, F. (2009). The Great Financial Crisis. Causes and Consequences. New York: Monthly Review Press.

Fuchs, C. (2010a). Alternative Media as Critical Media. European Journal of Social Theory, 13(2), 173-192.

Fuchs, C. (2010b). Foundations of Critical Media and Information Studies. New York: Routledge.

Fuchs, C. (2010c). Grounding Critical Communication Studies. An Inquiry into the Communication Theory of Karl Marx. Journal of Communication Inquiry, 34(1), 15-41.

Fuchs, C. (2010d) Labor in Informational Capitalism and on the Internet. The Information Society, 26(3), 179-196.

Gowan, P. (2009). Crisis in the Heartland. New Left Review, 55, 5-29.

Grossberg, L. (2010). Modernity and Commensuration. A Reading of Contemporary (Economic) Crisis. Cultural Studies, 24(3), 295-332.

Hardt, M., \& Negri, A. (2009). Commonwealth. Cambridge, MA: Belknap Press.

Harman, C. (2010). Zombie Capitalism. London: Bookmarks Publications.

Harvey, D. (2009). Interview. Socialist Review, 2009(4).

Harvey, D. (2010). The Enigma of Capital. London: Profile Books.

Hayward, M. (2010). The Economic Crisis and After. Cultural Studies, 24(3), 283-294.

Hegel, G.W.F. (1874). The Logic. Encyclopaedia Part 1. London: Oxford University Press.

Hope, W. (2010). Time, Communication, and Financial Collapse. International Journal of Communication, 4, 649-669.

Klein, N. (2007). The Shock Doctrine. London: Penguin.

Krugman, P. (2009). The Return of Depression Economics and the Crisis of 2008. New York: W. W. Norton \& Company. Lapavitsas, C. (2009). Financialised Capitalism: Crisis and Financial Expropriation. Historical Materialism, 17(2), 114-148. Marx, K., \& Engels, F. (MEW) Werke. Berlin: Dietz.

McChesney, R.W., Foster, J.B., Stole, I.L. \& Holleman, H. (2009). The Sales Effort and Monopoly Capital. Monthly Review, 60(11), 1-23.

McChesney, R.W., \& Nicholis, J. (2010a). How to Save Journalism. The Nation, January 25, 2010.

McChesney, R.W., \& Nicholis, J. (2010b). The Death and Life of American Journalism. New York: Nation Books.

Moseley, Fred. (2009). The U.S. Economic Crisis: Causes and Solutions. International Socialist Review, 64(2).

Rossiter, N. (2006). Organized Networks: Media Theory, Creative Labour, New Institutions, Rotterdam: NAi Publishers.

Sandoval, M., \& Fuchs, C. (2010). Towards a Critical Theory of Alternative Media. Telematics and Informatics (special issue on community media, edited by Nico Carpentier and Salvatore Scifo), 27(2), 141-150.

Smythe, Dallas W. (1981/2006). On the Audience Commodity and its Work. In M.G. Durham \& D.M. Kellner (Eds.), Media and Cultural Studies KeyWorks (pp. 230-256). Malden, MA: Blackwell. 
Stiglitz, J. (2008). Global Crisis - Made in America. Spiegel Online. Retrieved July 9, 2010, from http://www.spiegel.de/international/business/0,1518,590028,00.html

Stiglitz, J. (2009). The Anatomy of a Murder: Who Killed America's Economy? Critical Review, 21(2).

Stiglitz, J. (2010). Freefall. Free Markets and the Sinking of the Global Economy. London: Allen Lane.

Wallerstein, I. (2010). Structural Crises. New Left Review, 62, 133-142.

Wolff, R.D. (2009). Capitalism Hits the Fan. The Global Economic Meltdown and What to Do About It. Northampton, MA: Interlink.

Žižek, S. (2008). In Defense of Lost Causes. London: Verso.

Žižek, S. (2009a). First as Tragedy, then as Farce. London: Verso.

Žižek, S. (2009b). How to Begin from the Beginning. New Left Review, 57, 43-55.

Žižek, S. (2010). Living in the End Times. London: Verso.

\section{About the Authors}

Christian Fuchs

Christian Fuchs is chair professor for media and communication studies at Uppsala University's Department of Informatics and Media (Institutionen för Informatik och Media) and editor of tripleC (cognition, communication, co-operation): Journal for a Global Sustainable Information Society. His main research fields are: social theory, critical theory, political economy of media, information, technology; information society studies, ICTs and society. He is author of numerous publications in these fields. He co-ordinates the research project "Social Networking Sites in the Surveillance Society" (2010-2013), which is funded by the Austrian Science Fund FWF.

\section{Matthias Schafranek}

Matthias Schafranek is member of the Unified Theory of Information Research Group and doctoral student at the University of Salzburg. From 1999 to 2002 he was research assistant to the SFB-Project of the Austrian Science Fund (FWF): Pluralism of Theories and Paradigms Within and Among Sciences. In 2007 Matthias joined the eThoery Group of the ICT\&S Center and extended his research focus on human cooperation to the new context of the web. His research interests are: critical political economy of commons-based peer production, knowledge commons, the renegotiation of intesssssllectual property in the digital age. http://uti.at/schafranek.html

\section{David Hakken}

David Hakken is professor for social informatics at Indiana University. He is an anthropologist whose ethnography of information aims to understand the ways automated information/communication technologies and social reproduction mutually shape each other. His research has been grounded in England, Scandinavia, Upstate New York, Malaysia and China. His most current work is on Open Computing (especially Free/Libre and/or Open Source Software) and Socially Robust and Enduring Computing. After twenty-six years in the State University of New York, he in 2004 began teaching social informatics in the new School of Informatics at Indiana University, promoting technologies that expand rather than undermine human capabilities. His book, The Knowledge Landscapes of Cyberspace, was published in 2003.

http://www.informatics.indiana.edu/people/profiles.asp?u=dhakken

\section{Marcus Breen}

Marcus Breen has worked as a journalist, researcher, consultant and academic in Australia, the US, Latin America and the Caribbean in and across the fields of culture industries, public policy and ICTs. He has taught at The University of Melbourne, The University of North Carolina at Chapel Hill and Northeastern University. His currently book project is titled ";Uprising: The Internet's Unintended Consequences". His publications include: Select publications: Rock Dogs: politics and the music industry in Australia, (reprint) University Press of America, Maryland, 2006, first published 1999 by Pluto Press, Australia. Our Place Our Music Aboriginal Music: Australian Popular Music in Perspective, (editor) Volume 2, Aboriginal Studies Press, Canberra, 1989. Missing In Action: Australian Popular Music in Perspective, (editor) Volume 1, Verbal Graphics, Melbourne, 1987.

http://www.commstudies.neu.edu/faculty and staff/marcus breen/ 